\title{
Perbandingan Pembobotan Seemingly Unrelated Regression - Spatial Durbin Model untuk Faktor Kemiskinan dan Pengangguran
}

\author{
Luh Putu Safitri Pratiwi ${ }^{1}$, Ni Putu Nanik Hendayanti ${ }^{2}$, I Ketut Putu Suniantara ${ }^{3}$ \\ 1,2,3 ITB STIKOM Bali \\ 1safitri.pratiwi@yahoo.com, ${ }^{2}$ nanik@stikom-bali.ac.id, ${ }^{3}$ suniantara@stikom-bali.ac.id \\ DOI 10.30812/varian.v3i2.596
}

\section{INFO ARTIKEL}

\section{Riwayat Artikel:}

Diterima: 17-12-2019

Disetujui: 09-01-2020

\section{Kata Kunci:}

Regresi

Spasial

OLS

SDM

\section{ABSTRAK}

Abstrak: Hukum I Tobler menduga segala sesuatu di suatu wilayah berhubungan erat dengan wilayah lainnya sehingga pemodelan analisis spasial lebih tepat digunakan untuk memodelkan faktor yang berpengaruh terhadap kemiskinan dan pengangguran di suatu wilayah dengan memperhatikan efek spasialnya Salah satu metode spasial yang bisa digunakan ialah Seemingly Unrelated Regression-Spatial Durbin Model (SUR-SDM). Penentuan matriks pembobot dalam penelitian ini menggunakan Queen Contiguity dan pembobot customize. Penelitian ini bertujuan untuk mendeskripsikan kemiskinan dan pengangguran menggunakan metode SURSDM dengan bobot Queen Contiguity dan Customize. Adapun variabel-variabel yang digunakan yaitu variabel respon terdiri dari persentase rumah tangga miskin (y1) dan angka pengangguran (y2). Sedangkan variabel bebasnya yaitu terdiri dari: persentase jumlah sarana pelayanan kesehatan $(\mathrm{x} 1)$, persentase jumlah sarana sekolah (x2), persentase penduduk yang bekerja di sektor pertanian (x3), persentase rumah tangga yang menggunakan air bersih (PDAM) (x4), dan rasio penduduk yang belum tamat SD (x5). Hasil yang didapat yaitu pemodelan SUR-SDM dengan bobot Customize menghasilkan nilai R-Square yang lebih kecil dibandingkan bobot Queen di kedua variable respon yaitu sebesar $80.60 \%$ dibandingkan Queen sebesar 80.64 untuk variable kemiskinan dan untuk variable pengangguran bobot Customize mengasilkan nilai 92.51\% lebih kecil dibanding Queen sebesar 92.53\%

\begin{abstract}
Tobler's Law I about everything in one region is closely related to other regions so that the modeling of spatial analysis is more appropriate to be used to model the factors that oppose poverty and bind in an area by paying attention to spatial influences. One of the spatial methods that can be used in Spatial-Regression apparently not related to the Durbin Model (SUR-SDM). The weighting matrix selection method in this study uses Queen Contiguity and weighting adjustments. This research is designed to describe poverty and purchasing as well as the factors that influence it using the SUR-SDM method with the weight of Queen Contiguity and Customize. While the variables used are response variables consisting of the percentage of poor households (y1) and win rates (y2). While the independent variable consists of: the total number of health services ( $x 1)$, number of facilities provided $(x 2)$, percentage of the population working in the agricultural sector (\%) (x3), percentage of households that use clean water (PDAM) ( $x 4)$, and the ratio of population not completing primary school (x5)). The results obtained are modeling of SUR-SDM with Adjustment weights resulting in a smaller $R$-Square value than the queen's weights in the two response variables that is $80.60 \%$ compared to the queen of 80.64 for the wealth variable and for the variable, increasing weights Adjusting the value of $92.51 \%$ less than the queen of $92.53 \%$
\end{abstract}




\section{A. LATAR BELAKANG}

Pembangunan ekonomi yang dilakukan oleh Pemerintah merupakan serangkaian kebijaksanaan yang bertujuan untuk meningkatkan taraf hidup masyarakat, memperluas lapangan kerja, pemerataan pendapatan masyarakat, dan meningkatkan hubungan setiap daerah. Akan tetapi tujuan lain pembangunan ekonomi yang tidak kalah penting adalah menurunkan angka kemiskinan dan pengangguran setiap kelompok masyarakat. Jumlah penduduk miskin dan pengangguran tidak akan dapat dikurangi secara signifikan tanpa adanya pertumbuhan ekonomi yang bermanfaat. Untuk menurunkan tingkat kemiskinan dan pengangguran, pertumbuhan ekonomi yang lebih tinggi merupakan suatu keharusan.

Kemiskinan didefinisikan sebagai ketidakmampuan individu dalam memenuhi kebutuhan dasar minimal untuk layak hidup, kemiskinan merupakan sebuah kondisi yang berada di bawah garis nilai standar kebutuhan minimum, baik untuk makanan dan nonmakanan yang disebut garis kemiskinan (poverty line) atau batas kemiskinan (poverty treshold) (Badan Pusat Statistik, 2002). Sedangkan pengangguran ialah penduduk yang sedang mencari pekerjaan tetapi tidak sedang mempunyai pekerjaan (Sumarsono, 2009). Masalah kemiskinan dan pengangguran masih menjadi polemik berkepanjangan di berbagai wilayah. Upaya pemerintah daerah untuk mengatasi masalah kemiskinan dan pengangguran dapat disiasati dengan mendeteksi faktor-faktor yang mempengaruhinya untuk menentukan kebijakan yang diambil. Hal yang dilakukan adalah dengan mengetahui faktor-faktor yang berpengaruh terhadap kemiskinan dan pengangguran menggunakan pemodelan statistik. Pemodelan spasial dilihat tepat untuk kasus ini karena kemiskinan dan pengangguran di suatu wilayah berhubungan dengan kemiskinan di wilayah lain. Pernyataan tersebut didukung dari hukum I Tobler yang berbunyi "segala sesuatu pasti memiliki hubungan dengan yang lain, tetapi sesuatu yang berdekatan memiliki pengaruh lebih daripada yang jauh". Seemingly Unrelated Regression (SUR) diperkenalkan pertama kali oleh Zellner (Zellner, 1962) melalui publikasi jurnal mengenai estimasi dan pengujian SUR dengan error berkorelasi. SUR telah diterapkan dalam banyak penelitian ekonomi dan penelitian-penelitian di bidang lainnya salah satunya Kapoor (Kapoor, Dlabay, \& Hughes, 2010) menggunakan pendekatan Generalized Moment Estimators (GM) untuk mengestimasi model SUR panel efek random spasial dengan SAR disturbances.

Dalam penelitian SUR SDM diperlukan pembobot yang digunakan untuk menghitung koefisien autokorelasi. Matriks pembobot yaitu matriks yang elemen-elemennya adalah nilai pembobot yang diberikan untuk perbandingan setiap daerah tertentu. Salah satu metode penentuan matriks pembobot dalam penelitian ini adalah Queen Contiguity, yaitu bernilai 1 untuk lokasi yang titik sudutnya bertemu dengan lokasi yang menjadi perhatian, bernilai 0 untuk lokasi lainnya. Selain Queen Contiguity tersebut terdapat jenis pembobot lain yaitu pembobot Customize. Pembobot Customize adalah pembobot yang tidak hanya mempertimbangkan letak wilayah tetapi juga faktor kedekatan ekonomi, transportasi, sosial, infrastruktur, ataupun faktor lainya.

Di Indonesia, penelitian mengenai Spatial Seemingly Unrelated Regression (SSUR) diantaranya dilakukan oleh Pristiandana (Pristyandana, 2013). Pristiandana (Pristyandana, 2013) mengkaji estimasi model SUR dengan memperhatikan efek spasial. Sedangkan SUR-SDM pernah diteliti oleh Misdiati (Misdiati, 2016), hasil penelitian yang di dapat ialah Model Seemingly Unrelated Regression-Spatial Durbin Model (SUR-SDM ) dengan bobot Customize menghasilkan nilai R-Square lebih tinggi dengan Root Mean Square Error (RMSE) lebih rendah dibandingkan dengan bobot Queen Contiguity untuk memodelkan faktor perekonomian kemiskinan, pengangguran, dan Produk Domestik Regional Bruto (PDRB) di Jawa Timur.

Berdasarkan hasil-hasil penelitian yang telah diuraikan di atas, maka SUR-SDM pada penelitian ini digunakan untuk menganalisis kemiskinan dan pengangguran dari sudut pandang kewilayahan.

\section{B. TINJAUAN PUSTAKA}

\section{Analisis Regresi}

Analisis Regresi merupakan metode yang digunakan untuk mengetahui pola hubungan antara variabel respon dan variabel bebas. Model persamaan regresi sebagai berikut. 


$$
Y=\beta_{0}+\beta_{1} X_{1}+\beta_{2} X_{2}+\cdots+\beta_{p} X_{p}+\varepsilon
$$

dengan:

a) Pengujian Serentak

Hipotesis yang digunakan untuk pengujian serentak adalah sebagai berikut.

$H_{0}: \beta_{1}=\beta_{2}=\cdots=\beta_{p}=0$

$H_{1}$ : minimal ada satu $\beta_{k} \neq 0 ; k=1,2, \ldots, p$

statistik uji untuk menghitung $F_{\text {hit }}$ dengan rumus (2):

$F_{\text {hit }}=\frac{M S R}{M S E}$

bandingkan nilai uji $F_{h i t}$ dengan nilai $F_{\text {tabel }}=F_{\alpha, p, n-(p+1)}$, dengan kriteria uji apabila nilai $F_{\text {hit }}$ lebih besar atau sama dengan nilai tabel $F_{\text {tabel }}$, maka $H_{0}$ ditolak.

b) Pengujian Parsial

Pengujian parameter regresi secara parsial dilakukan untuk mengetahui parameter yang signifikan memengaruhi variabel dependen. Hipotesis untuk pengujiannya sebagai berikut.

$H_{0}: \beta_{k}=0$

$H_{1}: \beta_{k} \neq 0 ; k=1,2, \ldots, p$

statistik uji sesuai rumus (3) di bawah ini:

$t_{\text {hit }}=\frac{\widehat{\beta}_{k}}{S\left(\widehat{\beta}_{k}\right)}$

jika $\left|t_{h i t}\right|>t_{\alpha / 2} ; n-(p+1)$ maka keputusan menolak $H_{0}$.

\section{Regresi Spasial}

Hukum pertama tentang geografi menyatakan bahwa segala sesuatu saling berhubungan satu dengan yang lainnya, tetapi sesuatu yang dekat mempunyai pengaruh lebih besar daripada sesuatu yang jauh (Anselin, 1988). Hukum yang dikemukakan Anselin merupakan dasar pengkajian permasalahan berdasarkan efek lokasi atau metode spasial. Metode spasial merupakan metode untuk mendapatkan informasi pengamatan yang dipengaruhi efek ruang atau lokasi. Pengaruh efek ruang tersebut disajikan dalam bentuk koordinat lokasi (longitude, latitude) atau pembobotan.

Pemodelan spasial mempunyai dua tipe data yaitu dapat dibedakan menjadi pemodelan dengan pendekatan titik dan area. Pengujian efek spasial dilakukan dengan uji heterogenitas dan dependensi spasial. Penyelesaian jika ada efek heterogenitas adalah dengan mengunakan pendekatan titik. Jenis pendekatan titik diantaranya Geographically Weighted Regression (GWR), Geographically Weighted Poisson Regression (GWPR), Space-Time Autoregressive (STAR), dan Generalized Space-Time Autoregressive (GSTAR). Penyelesaian jika ada efek dependensi spasial adalah dengan mengunakan pendekatan area. Pendekatan area diantaranya Spatial Autoregressive Model (SAR), Spatial Error Model (SERM), Spatial Durbin Model (SDM), Conditional Autoregressive Model (CAR), dan Spatial Autoregressive Moving Average (SARMA).

SDM merupakan kasus khusus dari model SAR dengan menambahkan pengaruh lag pada variabel independen, sehingga pembobotan dilakukan pada variabel independen maupun dependen.

\section{Metode Regresi Spasial}

Menurut Anselin (Anselin, 1988) bahwa model regresi yang melibatkan pengaruh spasial disebut model regresi spasial. Salah satu pengaruh spasial yaitu autokorelasi spasial, adanya unsur autokorelasi spasial mengakibatkan terbentuknya parameter spasial autoregresif dan moving average, sehingga terbentuk proses spasial sebagai berikut:

$$
\begin{aligned}
& y=\rho W_{1} y+X \beta+u \\
& u_{t}=\lambda W_{2} u_{t-1}+\varepsilon \\
& \varepsilon \sim N\left(0, \sigma^{2} \mathrm{I}\right)
\end{aligned}
$$


sehingga model umum yang terbentuk adalah:

$$
\boldsymbol{y}=\rho W_{1} y+X \beta+\lambda W_{2} u+\varepsilon
$$

dengan $y$ merupakan vektor variabel dependen yang berukuran $n \times 1, \rho$ adalah parameter koefisien spasial lag variabel dependen, $\lambda$ adalah parameter koefisien spasial lag error, $u$ merupakan vektor error yang berukuran $n \times 1$, dan $\varepsilon$ merupakan vektor errorberukuran $n \times 1$, yang berdistribusi normal dengan mean nol dan varians $\sigma^{2}$ I. Sementara itu, $W_{1}$ dan $W_{2}$ merupakan matriks pembobot dengan ukuran $n \times n$ dimana $W_{1}=W_{2}=W$. Vektor parameter koefisien regresi dilambangkan dengan $\beta$ yang berukuran $(p+1) \times 1$. Matriks $X$ merupakan matriks variabel independen yang berukuran $n \times(p+1)$, merupakan matriks identitas yang berukuran $n \times n, n$ banyak amatan atau lokasi $(i=1,2,3, \ldots, n)$, dan $p$ banyak variabel independen.

\section{Seemingly Unrelated Regression (SUR)}

Seemingly Unrelated Regression (SUR) merupakan metode dalam spatial econometrics berupa generalisasi dari model regresi linear sederhana yang terdiri dari beberapa persamaan regresi, dimana setiap persamaan regresi memiliki variabel dependen yang berbeda-beda dan himpunan variabel independen yang dimungkinkan berbeda pula. Zellner (Zellner, 1962) pertama kali memperkenalkan SUR dalam bidang ekonometrika karena adanya korelasi error pada sistem persamaan regresi. Kelebihan SUR diantaranya adalah efisien dalam mengestimasi parameter karena melibatkan semua persamaan regresi dan error contemporaneous dalam perhitungan estimasinya.

Secara umum model SUR untuk $m$ buah persamaan regresi sebanyak prediktor dituliskan sebagai.

$$
\begin{aligned}
& y_{1 i}=\beta_{10}+\beta_{11} x_{1 i .1}+\beta_{12} x_{1 i 2}+\cdots+\beta_{1 p_{1}} x_{1 i p_{1}}+\varepsilon_{1 i} \\
& y_{2 i}=\beta_{20}+\beta_{21} x_{2 i .1}+\beta_{22} x_{2 i 2}+\cdots+\beta_{2 p_{2}} x_{2 i p_{2}}+\varepsilon_{2 i} \\
& \vdots \\
& y_{j i}=\beta_{j 0}+\beta_{j 1} x_{j i .1}+\beta_{j 2} x_{j i 2}+\cdots+\beta_{j p_{j}} x_{j i p_{j}}+\varepsilon_{j i} \quad ; i=1,2, \cdots, n \\
& \vdots \\
& y_{m i}=\beta_{m 0}+\beta_{m 1} x_{m i .1}+\beta_{m 2} x_{m i 2}+\cdots+\beta_{m p_{m}} x_{m i p_{m}}+\varepsilon_{m i}
\end{aligned}
$$

Estimasi parameter SUR menggunakan Generalized Least Square sebagai berikut

$$
\hat{\beta}=\left(X^{T} \Omega^{-1} X\right)^{-1} X^{T} \Omega^{-1} y
$$

Berikut ini adalah struktur matriks varians-kovarians dalam pemodelan SUR

$$
\begin{aligned}
& E\left(\varepsilon \varepsilon^{T}\right)=\sum \otimes I_{n}=\Omega \\
& \sum_{m \times m}=\left(\begin{array}{cccc}
\sigma_{11} & \sigma_{12} & \cdots & \sigma_{1 m} \\
\sigma_{21} & \sigma_{22} & \cdots & \sigma_{2 m} \\
\vdots & \vdots & \ddots & \vdots \\
\sigma_{m 1} & \sigma_{m 2} & \cdots & \sigma_{m m}
\end{array}\right)
\end{aligned}
$$

$\Sigma_{m_{x} m}$ adalah matriks varians-kovarians

\section{SUR-SDM (Seemingly Unrelated Spatial Durbin Model)}

Model SUR-SDM adalah pengembangan dari model SUR-SAR (Anselin, 1988). Mur dan López (Mur \& López, 2010) yang mengakomodasi adanya efek spasial tidak hanya pada variabel dependen, tetapi juga variabel independen. Struktur model SUR-SDM diuraikan sebagai berikut. 


$$
\begin{aligned}
& y_{j}=\rho_{j} W y_{j}+X_{j} \beta+W X_{j} \gamma+\varepsilon_{j} \\
& \Rightarrow A_{j} y_{j}=X_{j} \beta+W X_{j} \gamma+\varepsilon_{j} \\
& A_{j}=I_{n}-\rho_{j} W
\end{aligned}
$$

Dalam bentuk matriks persamaan tersebut dinotasikan seperti persamaan (5).

$$
\begin{aligned}
& A y=X \beta+W X \gamma+\varepsilon \\
& \varepsilon \sim N(0, \Omega)
\end{aligned}
$$

Singkatnya model SUR-SDM tersebut dituliskan dalam bentuk matriks dengan element-element yang dinyatakan sebagai berikut

$$
\begin{aligned}
& A y=Z_{s} \delta_{s} \\
& \varepsilon \sim N(0, \Omega)
\end{aligned}
$$

Pengujian terhadap parameter model dilakukan untuk mengetahui peranan variabel bebas dalam model. Uji Wald digunakan untuk menguji parameter $\beta_{j}$. Rumus untuk uji Wald berdasarkan hipotesis Anselin [7].

$$
\begin{aligned}
& H_{0}: \widehat{\beta}_{j}=0 \\
& H_{1}: \widehat{\beta}_{j} \neq 0
\end{aligned}
$$

statistik uji yang digunakan adalah pada persamaan (6).

$$
\text { Wald }=\left[\frac{\widehat{\beta}_{j}^{2}}{\operatorname{var}\left(\widehat{\beta}_{j}\right)}\right]
$$

dengan $\widehat{\beta}_{j}$ menyatakan penduga parameter ke-j, dan $\operatorname{var}\left(\widehat{\beta}_{j}\right)$ menyatakan varian parameter ke-j. Kriteria pengambilan keputusan adalah mengikuti sebaran $\chi_{\alpha, 1}^{2}{ } \quad H_{0}$ ditolak jika nilai Wald $>\chi_{\alpha, 1}^{2}$.

\section{Uji Efek Spasial}

Anselin (Anselin, 1988) membedakan efek spasial menjadi dua bagian yaitu dependensi spasial dan heterogenitas spasial. Dependensi spasial ditunjukkan dengan kemiripan sifat untuk lokasi yang saling berdekatan, sedangkan heterogenitas spasial ditunjukkan oleh perbedaan sifat antara satu lokasi dengan lokasi lainnya.

a) Uji Dependensi Spasial

Anselin (Anselin, 1988) menyatakan bahwa uji untuk mengetahui dependensi spasial di dalam error suatu model dengan menggunakan statistik Moran's I.

Hipotesis yang digunakan adalah:

$H_{0}: \mathrm{I}_{M}=0$ (tidak ada dependensi antarlokasi)

$H_{1}: \mathrm{I}_{M} \neq 0$ (ada dependensi antarlokasi)

statistik uji disajikan pada persamaan yaitu:

$$
Z_{\text {hitung }}=\frac{\mathrm{I}_{M}-\mathrm{I}_{M O}}{\sqrt{\operatorname{var}\left(\mathrm{I}_{M}\right)}}
$$

dengan $x_{i}$ merupakan data ke- $i(i=1, \ldots, n), x_{j}$ merupakan data ke- $j(j=1, \ldots, n), \bar{X}$ merupakan rata-rata data, $\operatorname{var}\left(\mathrm{I}_{M}\right)$ merupakan varians Moran's I, E $\left(\mathrm{I}_{M}\right)$ merupakan expected value Moran's I. Jika $\left|z_{h i t}\right|>Z \alpha / 2$ maka keputusan diambil adalah menolak $H_{0}$ (Pristyandana, 2013). Nilai dari indeks $\mathrm{I}_{M}$ adalah antara -1 dan 1 , jika $\mathrm{I}_{M}>\mathrm{I}_{M O}$ maka data memiliki autokorelasi positif, jika $\mathrm{I}_{M}<\mathrm{I}_{M O}$ maka data memiliki autokorelasi negatif. Pola penyebaran antar lokasi dapat disajikan Moran's Scatterplot Gambar 1.

Misdiati (Misdiati, 2016) menyebutkan bahwa Moran's Scatterplot dibagi atas empat kuadran yang cocok untuk empat pola kumpulan spasial lokal setiap daerah yang bertetangga. Berikut adalah penjelasan dari masing-masing kuadran (Pristyandana, 2013). 
(1) Kuadran I (terletak di kanan atas) disebut High-High (HH) menunjukkan daerah yang memiliki pengamatan tinggi yang dikelilingi oleh daerah yang juga memiliki pengamatan tinggi untuk variabel yang dianalisis.

(2) Kuadran II (terletak di kiri atas) disebut Low-High (LH) menunjukkan daerah dengan nilai rendah tapi dikelilingi daerah dengan nilai tinggi.

(3) Kuadran III (terletak di kiri bawah) disebut Low-Low (LL) menunjukkan daerah dengan nilai pengamatan rendah dan dikelilingi oleh daerah yang juga mempunyai nilai pengamatan rendah.

(4) Kuadran IV disebut High-Low (HL) menunjukkan daerah dengan nilai tinggi yang dikelilingi daerah dengan nilai rendah.

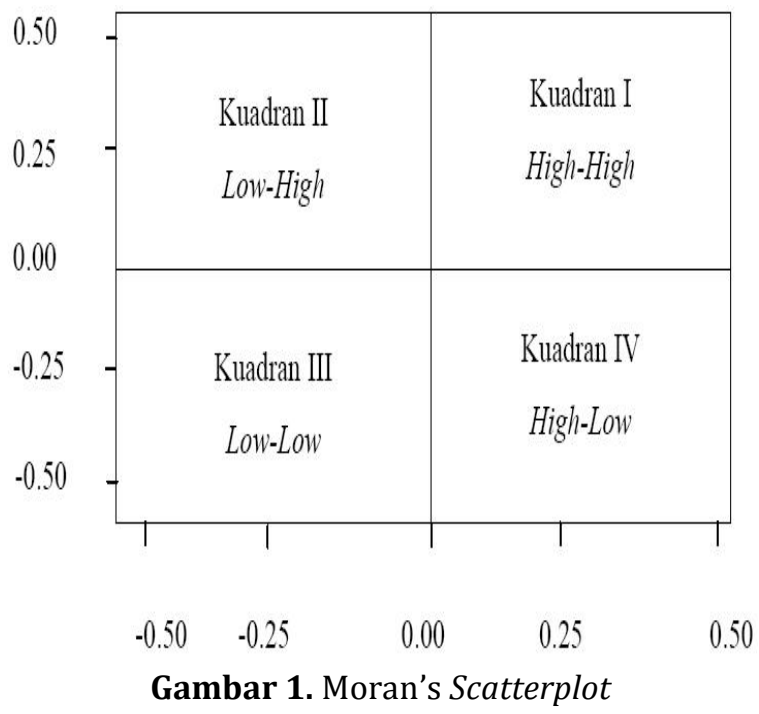

b) Uji Heterogenitas Spasial

Uji heterogenitas spasial digunakan untuk menunjukkan adanya keragaman antarlokasi. Heterogenitas data secara spasial dapat diuji dengan menggunakan Breusch-Pagan Test [2] yang hipotesisnya sebagai berikut:

$H_{0}: \sigma_{1}^{2}=\sigma_{2}^{2}=\cdots=\sigma_{n}^{2}=\sigma^{2}$ (homoskedastisitas)

$H_{1}$ : minimal ada satu $\sigma_{i}^{2} \neq \sigma^{2}$ (heterokedastisitas)

nilai Breusch-Pagan Test (BP Test) adalah:

$$
B P=(1 / 2) f^{T} Z\left(Z^{T} Z\right)^{-1} Z^{T} f \sim \chi_{k}^{2}
$$

dengan elemen vektor $f$ adalah:

$$
f_{i}=\left(\frac{e_{i}^{2}}{\sigma^{2}}-1\right)
$$

dengan $e_{i}$ merupakan least squares residual untuk observasi ke- $i, Z$ merupakan matriks berukuran $n \times(k+$ 1)yang sudah dinormalstandarkan $(z)$ untuk setiap observasi.

Tolak $H_{0}$ jika $B P>\chi_{k}^{2}$.

\section{Matriks Pembobot Spasial}

Matriks pembobot digunakan untuk menghitung koefisien autokorelasi. Matriks pembobot yaitu matriks yang elemen-elemennya adalah nilai pembobot yang diberikan untuk perbandingan setiap daerah tertentu.

Matriks bobot tipe data spasial area terdiri dari: Rook Contiguity (persinggungan sisi), Queen Contiguity (persinggungan sisi sudut), Linear Contiguity (persinggungan tepi), Bhisop Contiguity (persinggungan sudut), Double Linear Contiguity (persinggungan dua tepi) Double Rook Contiguity (persinggungan dua sisi) (Lesage, 1999). Lee dan Wong (Lee \& Wong, 2001) menyebutkan bahwa binary matrix atau contiguity matrix sebagai 
connectivity matrix dengan semua elemen diagonal matriknya bernilai 0 , karena diasumsikan bahwa suatu unit daerah tidak berdekatan dengan dirinya sendiri. Pada dasarnya matriks contiguity menggambarkan hubungan timbal balik dari hubungan spasial, sehingga matrik segitiga atas sepanjang diagonal utama merupakan cermin dari segitiga bawah. Baris dalam matriks contiguity menunjukkan bagaimana suatu daerah berhubungan spasial dengan daerah lain, sehingga jumlah nilai pada baris ke- $i$ merupakan jumlah tetangga yang dimiliki oleh daerah ke-i.

Salah satu metode penentuan matriks pembobot dalam penelitian ini adalah Queen Contiguity, dengan setiap elemen matriksnya menggambarkan kedekatan antara $i$ dan $j$ yang berukuran $n \times n$. Definisi metode Queen Contiguity yaitu $w_{i j}=1$ untuk lokasi yang titik sudutnya bertemu dengan lokasi yang menjadi perhatian, $w_{i j}=0$ untuk lokasi lainnya.

Gambar 2. merupakan ilustrasi mengenai perhitungan matriks pembobot Queen Contiguity yang menggunakan lima daerah sebagai pengamatannya. Untuk tiga lokasi didapatkan $w_{32}=1, w_{34}=1, w_{35}=1$ dan yang lain sama dengan nol. Matriks $w_{i j}$ ini memiliki ukuran matriks $5 \times 5$.

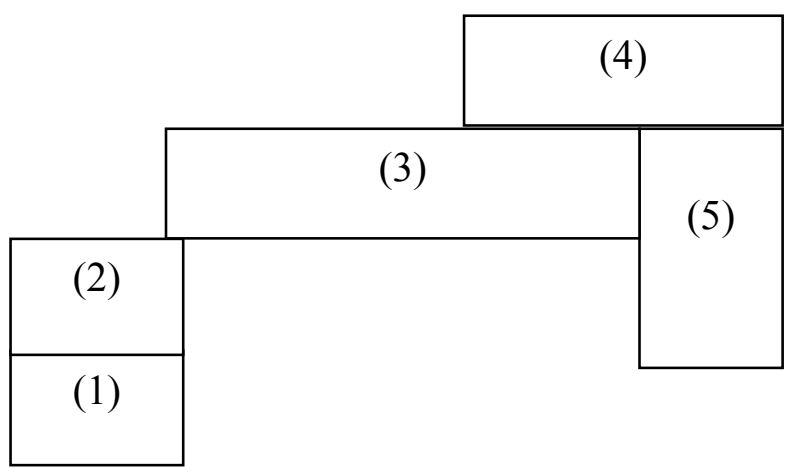

Gambar 2. Ilustrasi Contiguity (persinggungan)

Sumber: Lesage (Lesage, 1999)

Matriks pembobot yang dapat terbentuk dari Gambar 2 adalah sebagai berikut.

$\left[\begin{array}{lllll}0 & 1 & 0 & 0 & 0 \\ 1 & 0 & 1 & 0 & 0 \\ 0 & 1 & 0 & 1 & 1 \\ 0 & 0 & 1 & 0 & 1 \\ 0 & 0 & 1 & 1 & 0\end{array}\right]$

Baris dan kolom di atas menunjukkan wilayah yang ada pada peta. Susunan matriks distandarisasi sehingga jumlah setiap baris sama dengan satu, maka matriksnya menjadi

$$
w_{\text {queen }}=\left[\begin{array}{ccccc}
0 & 1 & 0 & 0 & 0 \\
1 / 2 & 0 & 1 / 2 & 0 & 0 \\
0 & 1 / 3 & 0 & 1 / 3 & 1 / 3 \\
0 & 0 & 1 / 2 & 0 & 1 / 2 \\
0 & 0 & 1 / 2 & 1 / 2 & 0
\end{array}\right]
$$

Selain keenam jenis pembobot contiguity tersebut terdapat jenis pembobot lain yaitu pembobot customize. Pembobot customize adalah pembobot yang tidak hanya mempertimbangkan letak wilayah tetapi juga faktor kedekatan ekonomi, transportasi, sosial, infrastruktur, ataupun faktor lainya.

\section{Ukuran Kebaikan Model}

Pada kasus pemodelan maupun prediksi untuk menentukan bahwa model yang diperoleh telah layak/baik, diperlukan ukuran yang menyatakan kebaikan suatu model. Kriteria kebaikan model yang 
digunakan pada penelitian ini adalah nilai R-Square dan RMSE (Root Mean Square Error). Perhitungan $R$ Square dan RMSE masing-masing disajikan pada rumus berikut

$$
\begin{aligned}
& R^{2}=\frac{S S R}{S S T}=\frac{\sum_{i=1}^{n}\left(\hat{y}_{i}-\bar{y}\right)^{2}}{\sum_{i=1}^{n}(y-\bar{y})^{2}} \\
& R M S E=\sqrt{\sum_{i=1}^{n}\left(y_{i}-\hat{y}_{i}\right)^{2}}
\end{aligned}
$$

Keterangan:

SSR : Sum Square Regression

SST : Sum Square Total

$n$ menyatakan banyaknya pengamatan, adalah nilai aktual, adalah nilai taksiran sedangkan adalah rata-rata semua pengamatan.

\section{METODE PENELITIAN}

\section{Sumber Data}

Data yang digunakan dalam penelitian ini berupa data sekunder yang diperoleh dari Badan Pusat Statistik (BPS) Kabupaten Gianyar, data tersebut adalah Publikasi Data Makro Sosial dan Ekonomi tahun 2017, data dari Badan Pemberdayaan Masyarakat dan Pemerintahan Desa (BPMPD) Provinsi Bali berupa data Pendataan Program Perlindungan Sosial (PPLS) tahun 2017, dan data dari Badan Perencanaan dan Pembangunan Daerah (Bappeda) Kabupaten Gianyar berupa Digitasi Peta Wilayah Administrasi Desa Kabupaten Gianyar tahun 2010-2030.

\section{Variabel Penelitian}

a. Variabel respon yaitu persentase rumah tangga miskin (\%) (y1) dan angka pengangguran (\%)(Y2)

b. Variabel bebasnya yaitu terdiri dari: persentase jumlah sarana pelayanan kesehatan meliputi posyandu puskesmas pembantu, dokter praktek, klinik bersalin, dan pos $\mathrm{KB}(\%)\left(\mathrm{X}_{1}\right)$, persentase jumlah sarana sekolah meliputi TK, SD, SLTP, SMU, dan SMK (\%) $\left(\mathrm{X}_{2}\right)$, persentase penduduk yang bekerja di sektor pertanian (\%) $\left(\mathrm{X}_{3}\right)$, persentase rumah tangga yang menggunakan air bersih (PDAM) (\%) $\left(\mathrm{X}_{4}\right)$, rasio penduduk yang belum tamat SD $\left(\mathrm{X}_{5}\right)$, dan persentase penduduk yang bekerja di sektor informal meliputi listrik/air minum, angkutan, perbankan/lembaga keuangan (\%) $\left(\mathrm{X}_{6}\right)$ kepala keluarga dengan pendidikan terakhir ayah SD atau SMP ( 3), angka buta huruf ( 4 ).

\section{Alur Analisis}

Adapun tahapan analisis data yang akan dilakukan dalam penelitian ini adalah sebagai berikut:

a. Mengidentifikasi pola hubungan antar variabel dependen dan variabel independen melalui Scatterplot.

b. Menstandardisasi data penelitian.

c. Melakukan pemodelan regresi linear berganda pada variabel dependen dan variabel independen.

d. Menentukan matriks pembobot spasial menggunakan pembobot Queen Contiguity.

e. Melakukan pengujian aspek spasial (dependensi spasial, heterogenitas spasial).

f. Melakukan pengujian model spasial melalui uji Lagrange Multiplier (LM).

g. Melakukan pemodelan dengan pendekatan SUR-SDM dengan bobot Queen Contiguity dan Customize.

h. Mengintrepetasikan model SUR-SDM dengan bobot terbaik.

i. Menginterpretasikan hasil analisis dan mengambil kesimpulan.

Tahapan-tahapan di atas dilakukan secara otomatis oleh komputer dengan menggunakan software Statistika. 


\section{HASIL DAN PEMBAHASAN}

\section{Identifikasi Pola Hubungan Antar Variabel}

Sebelum melakukan pemodelan Ordinary Least Square (OLS) dan pemodelan SUR SDM, maka dilakukan identifikasi korelasi antara variabel dependen terhadap variabel independen pada Tabel 1.

Tabel 1. Korelasi Variabel Dependen Terhadap Variabel Independen

\begin{tabular}{ccccc}
\hline \multirow{2}{*}{ Prediktor } & \multicolumn{2}{c}{$\begin{array}{c}\text { Persentase Rumah Tangga } \\
\text { Miskin }(\%)\left(\mathrm{Y}_{1}\right)\end{array}$} & \multicolumn{2}{c}{ Angka Pengangguran $(\%)\left(\mathrm{Y}_{2}\right)$} \\
\cline { 2 - 5 } & kor & Sig. & Kor & Sig. \\
\hline$\left(\mathrm{X}_{1}\right)$ & 0,139 & 0,252 & 0,150 & 0,215 \\
\hline$\left(\mathrm{X}_{2}\right)$ & 0,490 & $0,000^{*}$ & $-0,080$ & 0,510 \\
\hline$\left(\mathrm{X}_{3}\right)$ & 0,070 & 0,564 & $-0,133$ & 0,273 \\
\hline$\left(\mathrm{X}_{4}\right)$ & 0,282 & 0,018 & $-0,216$ & 0,072 \\
\hline$\left(\mathrm{X}_{5}\right)$ & 0,328 & $0,006^{*}$ & 0,014 & 0,911 \\
\hline$\left(\mathrm{X}_{6}\right)$ & 0,097 & 0,422 & 0,381 & $0,001^{*}$ \\
\hline
\end{tabular}

Berdasarkan hasil Tabel 1 dapat dijelaskan bahwa variabel prediktor persentase jumlah sarana pelayanan kesehatan, persentase jumlah sarana sekolah, persentase penduduk yang bekerja di sektor pertanian, persentase rumah tangga yang menggunakan air bersih (PDAM), dan rasio penduduk yang belum tamat SD, dan persentase penduduk yang bekerja di sektor informal memiliki korelasi signifikan terhadap kemiskinan. Korelasi positif tinggi terjadi pada variabel persentase jumlah sarana sekolah sebesar 0.490 .

Sementara jumlah sarana sekolah terhadap pengangguran adalah signifikan positif dengan nilai korelasi masing-masing 0.150 dan 0.014 . Sedangkan untuk persentase jumlah sarana sekolah, persentase penduduk yang bekerja di sektor pertanian, persentase rumah tangga yang menggunakan air bersih (PDAM) berkorelasi negatif dengan angka $-0,080 ;-0,133 ;-0,216$.

Selain menampilkan korelasi antara variabel dependen dan independen, untuk melihat apakah terdapat korelasi diantara variabel independen, maka disajikan Tabel 2 yang berisi nilai korelasi antar variabel independennya.

Tabel 2. Korelasi antar Variabel Independen

\begin{tabular}{clllll}
\hline Kor & $X_{1}$ & $X_{2}$ & $X_{3}$ & $X_{4}$ & $X_{5}$ \\
\hline$X_{2}$ & 0,266 & & & & \\
sig & $\mathbf{0 , 0 2 6}$ & & & & \\
\hline$X_{3}$ & 0,000 & $-0,166$ & & & \\
Sig & 0,998 & 0,170 & & & \\
\hline$X_{4}$ & $-0,085$ & $-0,023$ & 0,496 & & \\
Sig & 0,486 & 0,851 & $\mathbf{0 , 0 0 0}$ & & \\
\hline$X_{5}$ & $-0,008$ & 0,240 & $-0,127$ & $-0,113$ & \\
Sig & 0,946 & $\mathbf{0 , 0 4 5}$ & 0,294 & 0,351 & \\
\hline$X_{6}$ & 0,304 & 0,040 & 0,200 & $-0,065$ & 0,257 \\
Sig & $\mathbf{0 , 0 1 0}$ & 0,741 & 0,097 & 0,592 & $\mathbf{0 , 0 3 2}$ \\
\hline
\end{tabular}

Sementara variabel persentase penduduk yang bekerja di sektor informal terlihat signifikan berhubungan denganpersentase jumlah sarana pelayanan kesehatan rasio penduduk yang belum tamat SD. 
Hal tersebut menunjukkan bahwa terjadi kasus multikolinieritas yang ditunjukkan oleh hubungan antar variabel independennya.

\section{Pemodelan Regresi Linier Berganda}

Sebelum memodelkan kasus lebih lanjut, untuk mengetahui pengaruh variabel independen pada masingmasing persamaan tunggal digunakan metode regresi linear berganda. Hasil estimasi parameter beta pada masing-masing persamaan disajikan pada Tabel 3 berikut.

Tabel 3. Estimasi Parameter

\begin{tabular}{ccccc}
\hline \multirow{2}{*}{ Var } & \multicolumn{2}{c}{$\begin{array}{c}\text { Persentase Rumah Tangga } \\
\text { Miskin }(\%)\left(\mathrm{Y}_{1}\right)\end{array}$} & \multicolumn{2}{c}{$\begin{array}{c}\text { Angka Pengangguran } \\
(\%)\left(\mathrm{Y}_{2}\right)\end{array}$} \\
\cline { 2 - 5 } & Koef. & Sig. & Koef. & Sig. \\
\hline$X_{1}$ & 25.172 & 0.646 & 0.135 & 0.745 \\
\hline$X_{2}$ & 0.398 & 0.000 & -0.003 & 0.330 \\
\hline$X_{3}$ & 0.020 & 0.930 & -0.001 & 0.137 \\
\hline$X_{4}$ & 0.610 & 0.007 & -0.041 & 0.457 \\
\hline$X_{5}$ & 15.034 & 0.019 & 0.006 & 0.001 \\
\hline$X_{6}$ & 0.035 & 0.878 & 0.055 & 0.384 \\
\hline
\end{tabular}

Berdasarkan hasil estimasi regresi linear berganda pada kedua variabel respon diperoleh bahwa variabel rasio penduduk yang belum tamat $\mathrm{SD}$, persentase rumah tangga yang menggunakan air bersih (PDAM) persentase jumlah sarana dan sekolah berpengaruh signifikan pada kemiskinan pada alfa 5\%. Sedangkan untuk variabel rasio penduduk yang belum tamat SD berpengaruh signifikan pada pengangguran.

Pemodelan SUR-SDM untuk memodelkan faktor perekonomian di Gianyar menggunakan matriks penimbang spasial Queen Contiguity didasarkan pada bentuk wilayah kabupaten kota di Gianyar yang tidak simetris. Sementara sebagai pembanding digunakan matriks pembobot Customize pembobotannya didasarkan pada variabel dependen kemiskinan, pengangguran. Artinya kabupaten/kota yang bertetangga langsung dengan kemiskinan tinggi, pengangguran tinggi akan diberikan nilai 1 sedangkan yang tidak bertetangga langsung akan diberikan bobot 0 .

\section{Pengujian Aspek Spasial Pada SUR-Spasial}

Pada dasarnya pengujian aspek spasial dilakukan untuk mengetahui adanya pengaruh spasial pada kasus kemiskinan, pengangguran di Kab Gianyar Bali. Aspek spasial yang diujikan meliputi dua hal yaitu dependensi spasial dan heterogenitas spasial. Hasil pengujian tersebut disajikan pada Tabel 4 berikut ini:

Tabel 4. Hasil Pengujian Aspek Spasial SUR-Spasial

\begin{tabular}{ccccc}
\hline \multirow{2}{*}{ Pengujian } & $\begin{array}{c}\text { Persentase Rumah Tangga } \\
\text { Miskin }(\%)\left(\mathrm{Y}_{1}\right)\end{array}$ & Angka Pengangguran $(\%)\left(\mathrm{Y}_{2}\right)$ \\
\cline { 2 - 5 } & Koef. & Sig. & Koef. & Sig. \\
\hline Morans I & 0.572 & 0.22 & 0.449 & 0.056 \\
\hline $\begin{array}{c}\text { Breush } \\
\text { Pagan }\end{array}$ & 8.824 & $\mathbf{0 . 0 3 9}$ & 8.686 & $\mathbf{0 . 0 4 7}$ \\
\hline
\end{tabular}

Berdasarkan hasil pengujian Morans'I pada Tabel 4 dengan alpha yang digunakan peneliti sebesar 0,05, pengujian Morans'I signifikan pada error untuk model kasus Pengangguran. Hal ini menunjukkan bahwa 
terdapat dependensi spasial pada error model angka pengangguran di Gianyar, Bali. Sementara untuk model kemiskinan dengan taraf signifikansi yang sama tidak ditemukan adanya dependensi spasial. Selain Morans'I pengujian Breush Pagan dilakukan untuk melihat apakah terdapat heterogenitas spasial pada error. Pada Tabel 4 dengan menggunakan alpha ditemukan terdapat heterogenitas spasial pada variabel kemiskinan, pengangguran.

Berdasarkan pengujian yang dilakukan pada Tabel 4 dapat diketahui bahwa pada salah satu model mengandung dependensi spasial dan secara keseluruhan terjadi heterogenitas spasial. Berdasarkan alasan ini disimpulkan bahwa terdapat aspek spasial pada kasus kemiskinan, pengangguran di Gianyar, Bali. Keberadaan efek spasial ini dapat ditindaklanjuti dengan menambahkan komponen spasial pada model SUR yang akan dibentuk.

Pentingnya pengujian aspek spasial adalah untuk mengetahui adanya efek spasial pada data kemiskinan dan pengangguran daerah kabupaten Gianyar. Uji Lagrange Multiplier dilakukan untuk mengetahui penambahan komponen spasial terdapat pada model/persamaan utama, error, atau keduanya. Tabel 5. menyajikan nilai LM SAR, LM SEM, dan LM SARMA masing-masing.

Tabel 5. Hasil Uji Lagrange Multiplier SUR-Spasial

\begin{tabular}{lll}
\hline Pengujian & Nilai & Sig. \\
\hline LM-SAR & 8.101 & 0.040 \\
LM-SEM & 0.044 & 0.999 \\
LM-SARMA & -0.033 & 0.998 \\
\hline
\end{tabular}

Berdasarkan hasil Tabel 5 menggunakan taraf signifikansi alpha diperoleh bahwa Lagrange Multiplier model SUR-SAR adalah yang paling tepat untuk data kasus kemiskinan, pengangguran di Gianyar dengan signifikansi kurang dari nilai 5\%. Sementara nilai Lagrange Multiplier model yang lain melebihi taraf signifikansi yang ditentukan.

Dasar ini digunakan sebagai acuhan model SUR-SDM selanjutnya, karena uji yang menyatakan hubungan variabel independen di satu wilayah terhadap variabel dependent di wilayah lain belum dikembangkan.

\section{Estimasi Parameter Model SUR-SDM}

Pada pemodelan SUR-SDM ini data yang digunakan distandartkan terlebih dahulu karena variasinya yang cukup besar. Aspek spasial pada pengolahan data diakomodasi oleh penggunaan matriks pembobot spasial yaitu Queen Contiguity dan Customize. Matriks pembobot Queen Contiguity adalah matrik pembobot spasial yang mempertimbangkan aspek persinggungan sisi dan sudut. Sedangkan matriks pembobot spasial Customize merupakan matriks pembobot spasial yang tidak hanya mempertimbangkan aspek persinggungan dan kedekatan antar lokasi/wilayah, tetapi juga mempertimbangkan dependensi antar wilayah berdasarkan fenomena real seperti aspek ekonomi, transportasi, dan sosial kemasyarakatan.

Berikut ini merupakan hasil estimasi parameter kasus kemiskinan dan pengangguran menggunakan metode SUR-SDM dengan kedua bobot tersebut.

Tabel 6. Estimasi Parameter Beta dan Gama Terstandartkan Dengan Bobot Queen

\begin{tabular}{|c|c|c|c|c|}
\hline \multirow[t]{2}{*}{ Prediktor } & \multicolumn{2}{|c|}{$\begin{array}{c}\text { Persentase Rumah Tangga } \\
\text { Miskin }(\%)\left(\mathrm{Y}_{1}\right)\end{array}$} & \multicolumn{2}{|c|}{ Angka Pengangguran $(\%)\left(\mathrm{Y}_{2}\right)$} \\
\hline & Custom & Queen & Custom & Queen \\
\hline Konstan & 0.0000 & 0.0000 & 0.0000 & 0.0000 \\
\hline$\left[\mathrm{X}_{1}\right]$ & 0.0901 & 0.0066 & 0.0720 & 0.0425 \\
\hline$\left[\mathrm{X}_{2}\right]$ & 0.6941 & 0.0544 & -0.2610 & -0.0966 \\
\hline$\left[\mathrm{X}_{3}\right]$ & -0.1820 & 0.1996 & 0.1880 & 0.1936 \\
\hline$\left[\mathrm{X}_{4}\right]$ & 0.7991 & 0.0787 & 0.4270 & 0.4549 \\
\hline$\left[\mathrm{X}_{5}\right]$ & 0.5294 & -0.1371 & 0.7350 & 0.6637 \\
\hline
\end{tabular}




\begin{tabular}{ccccc}
\hline$\left[\mathrm{X}_{6}\right]$ & 0.0211 & 0.1317 & 0.0940 & 0.0509 \\
\hline$\left[\mathrm{WX}_{1}\right]$ & 0.1354 & 0.0185 & 0.0000 & 0.0864 \\
\hline$\left[\mathrm{WX}_{2}\right]$ & -0.2540 & -0.2741 & 0.0350 & 0.1334 \\
\hline$\left[\mathrm{WX}_{3}\right]$ & -0.1941 & 0.1403 & 0.0840 & 0.1430 \\
\hline$\left[\mathrm{WX}_{4}\right]$ & 0.0198 & 0.0826 & 0.0010 & -0.0380 \\
\hline$\left[\mathrm{WX}_{5}\right]$ & 0.0790 & 0.5227 & 0.5590 & 0.1309 \\
\hline$\left[\mathrm{WX}_{6}\right]$ & 0.0978 & 0.0356 & -0.4740 & 0.0298 \\
\hline Rho & 0.7887 & 0.8922 & 0.9000 & 0.9006 \\
\hline R-Square & $80.60 \%$ & $80.64 \%$ & $92.51 \%$ & $92.53 \%$ \\
\hline RMSE & 0.4848 & 0.4716 & 0.389 & 0.3805 \\
\hline
\end{tabular}

Dengan menggunakan model SUR-SDM dengan bobot Queen dan Customize diperoleh bahwa sebagian besar tanda koefisien parameter beta telah sesuai dengan keadaan real dilapangan. Nilai estimasi parameter pada Tabel 6 didapatkan melalui iterasi Newton-Rapshon.

Berdasarkan Tabel 6 terlihat bahwa berdasarkan nilai R-Square dan RMSE model SUR-SDM dengan bobot Queen adalah model terbaik untuk memodelkan variable dependent, karena memiliki nilai $R$-Square yang lebih tinggi dan RMSE yang lebih rendah dibandingkan bobot Customize.

\section{Interpretasi Model SUR-SDM}

Berdasarkan hasil estimasi parameter model SUR-SDM pada Tabel 6 diperoleh model kasus kemiskinan, pengangguran dengan bobot Queen. Model SUR-SDM yang akan dibentuk memiliki dari 70 desa, 2 persamaan regresi pada setiap variabel dependen dan 6 variabel independen pada setiap respon. Berikut merupakan rincian detail model SUR-SDM secara umum untuk kasus kemiskinan, pengangguran di Kabupaten Gianyar.

Model umum kemiskinan :

Untuk melihat aplikasinya model SUR-SDM pada satu daerah, maka akan diberikan model kemiskinan untuk Desa Manukaya :

$$
\begin{aligned}
& \hat{R}_{1(\text { manukaya })}=0,8922(0.5)\left(R_{1(\text { pupuan })}+R_{1(\text { tampaksiring })}\right) \\
& +0.0066 Z_{1}+0.0544 Z_{2}+0.1996 Z_{3} \\
& +0.0787 Z_{4}-0.1371 Z_{5}+0.1317 Z_{6} \\
& +0.0185(0.5)\left(R_{1(\text { pupuan })}+R_{1(\text { tampaksiring })}\right) \\
& +0.2741(0.5)\left(R_{\mathrm{l}(\text { pupuan })}+R_{\mathrm{l}(\text { tampaksiring })}\right) \\
& +0.1403(0.5)\left(R_{\mathrm{l}(\text { pupuan })}+R_{\mathrm{l}(\text { tampaksiring })}\right) \\
& +0.0826(0.5)\left(R_{\mathrm{l}(\text { pupuan })}+R_{\mathrm{1}(\text { tampalsiring })}\right) \\
& +0.5227(0.5)\left(R_{\mathrm{I}(\text { pupuan })}+R_{\mathrm{I}(\text { tampaksiring })}\right) \\
& +0.0356(0.5)\left(R_{\mathrm{l}(\text { pupuan })}+R_{\mathrm{l}(\text { tampalsiring })}\right)
\end{aligned}
$$

Berdasarkan model kemiskinan tersebut terlihat bahwa kemiskinan di Desa Manukaya dipengaruhi oleh kemiskinan di Desa Pupuan dan Tampaksiring masing-masing dengan bobot 0.5. Dari model tersebut diketahui pula kemiskinan di Desa Manukaya diduga dipengaruhi oleh persentase rumah tangga yang menggunakan air bersih (PDAM) $(\%)\left(x_{4}\right)$ di daerah Pupuan dan Tampaksiring dengan nilai koefisien yang berbeda-beda.

\section{E. SIMPULAN DAN SARAN}

1. Simpulan 
Berdasarkan analisis dan pembahasan diperoleh beberapa kesimpulan sebagai berikut ini : variabel rasio penduduk yang belum tamat $\mathrm{SD}$, persentase rumah tangga yang menggunakan air bersih (PDAM) persentase jumlah sarana dan sekolah berpengaruh signifikan pada kemiskinan. Sedangkan untuk variabel rasio penduduk yang belum tamat SD berpengaruh signifikan pada pengangguran. Model Seemingly Unrelated Regression-Spatial Durbin Model (SUR-SDM) dengan bobot Customize menghasilkan nilai R-Square lebih kecil dengan RMSE lebih tinggi dibandingkan dengan bobot Customize untuk memodelkan faktor kemiskinan dan pengangguran, di Gianyar, Bali.

\section{Saran}

Pengkajian pengujian hipotesis signifikansi parameter model SUR-SDM belum dilakukan dalam penelitian ini. Pada penelitian selanjutnya diharapkan penelitian yang lebih mendalam terhadap signifikansi parameter estimasi. Selain itu perlu diperhatikan pada model kemiskinan asumsi residual independen belum terpenuhi. Pada penelitian ke depan diharapkan dalam memodelkan kasus kemiskinan, pengangguran digunakan data panel sehingga autokorelasi antar pengamatan berdasarkan waktu dapat diakomodasi dengan baik.

\section{REFERENSI}

Anselin, L. (1988). Spatial Econometrics: Methods and Models. Netherland: Springer Netherlands.

Badan Pusat Statistik. (2002). Penduduk Fakir Miskin Indonesia 2002. Jakarta.

Kapoor, J. R., Dlabay, L. R., \& Hughes, R. J. (2010). Personal Finance (10th ed.). New York: McGraw-Hill. Lee, J., \& Wong, D. W. S. (2001). Statistical Analysis with Arcview GIS. New York: John Wiley.

Lesage, J. P. (1999). The Theory and Practice of Spatial Econometrics. Toledo Ohio: University of Toledo. Misdiati, L. (2016). Pemodelan Faktor Perkonomian di Jawa Timur Menggunakan Seemingly Unrelated Regression-Spatial Durbin Model. Institut Teknologi Sepuluh Nopember.

Mur, J., \& López, F. (2010). Spatial SUR models: Specification, Testing and Selection . (May), 1-45.

Pristyandana, A. H. (2013). Seemingly Unrelated Regression SUR Spasial untuk Memodelkan PDRB Sektor Unggulan di Jawa Timur. Institut Teknologi Sepuluh Nopember.

Sumarsono, S. (2009). Teori dan kebijakan publik ekonomi sumber daya manusia (1st ed.). Yogyakarta: Ghara Ilmu.

Zellner, A. (1962). An Efficient Method of Estimating Seemingly Unrelated Regressions and Tests for Aggregation Bias. Journal of the American Statistical Association, 57(298), 348-368. 
64 | Jurnal Varian| Vol. 3, No. 2, April 2020, Hal. 51-64 